\title{
PULMONARY INVOLVEMENT IN PATIENTS WITH HTLV-I ASSOCIATED MYELOPATHY
}

\author{
KILMA MATTOS, AILTON MELO, CONCEIÇÃO QUEIROZ, LEANDRO PUBLIO, \\ ANTONIO CARLOS PECSANHA-MARTINS, VIRGINIA FREITAS, IRENIO GOMES
}

SUMMARY - Pulmonary involvement in HTLV-I patients has been identified by several authors in Africa, Japan and Brazil. The objective of this controlled study is to establish an association between HAM and lymphocytosis in the bronchoalveolar fluid (BAL). Thirty-five adult patients with non-traumatic and non-tumoral myelopathy filled out a detailed historical survey and underwent a neurological examination, a thoracic radiological evaluation and a CSF examination. Of the patients in this sample, 22 were diagnosed with HTLV-I associated myelopathy and 13 had myelopathies with other etiologies. Lymphocytosis in the BAL fluid was detected in 18 $(82 \%)$ of the HAM patients and in $2(15 \%)$ of non-HAM patients. We concluded that the lung represents an important organ in the pathogenesis of HAM.

KEY WORDS: HTLV-I, TSP, encephalomyeloneuropathy, myelopathy, HTLV-I associated myelopathy (HAM), alveolitis.

\section{Comprometimento pulmonar em pacientes com mielopatia associada ao HTLV-I}

RESUMO - A frequência do comprometimento pulmonar em pacientes com doença neurológica associada ao primeiro virus linfotrópico humano de células T (HTLV-I) tem sido demonstrado por vários autores na África, Ásia e América Latina. Com o objetivo de estudar o envolvimento pulmonar em pacientes com mielopatia por HTLV-I (HAM) estudamos o lavado bronco-alveolar (LBA) de 22 pacientes com HAM e 13 pacientes com mielopatias de outras etiologias. A contagem diferencial das células do LBA de pacientes com HAM demonstrou percentual de linfócitos maior que $20 \mathrm{em} 18(82 \%)$ dos pacientes enquanto aqueles com mielopatias de outra natureza mostraram linfocitose no LBA em apenas $2(15 \%)$. Concluimos que o pulmão se constitui em importante orgão para a patogênese de HAM.

PALAVRAS-CHAVE: HTLV-I, TSP, encefalomieloneuropatia, mielopatia, HAM, alveolites.

The involvement of the nervous system by humanT-lymphotropic virus type-I (HTLV-I) is characterized as a slowly progressing spastic paraparesis frequently accompanied by mild sensory disturbances and spinal cord levels, bladder and bowel dysfunction, impotence, peripheral neuropathy and magnetic resonance signals of encephalic involvement ${ }^{7,-11}$. Systemic manifestations of HTLV-I infection have been described in patients with chronic spastic paraparesis. It has been shown that patients with HTLV-I associated myelopathy (HAM) are frequently associated with vasculitis, ichtiosis, Sjogren syndrome, and other immunological diseases ${ }^{3,4,6}$. Gessain et al. ${ }^{2}$ have reported evidence of pulmonary involvement in patients with HAM and subsequently several authors described lymphocytosis in the bronchoalveolar lavage (BAL) fluid of patients with $\mathrm{HAM}^{1,8,13}$. The proliferation of peripheral blood mononuclear cells (PBMC), production of interleukin-2 (IL-2), polyclonal

Federal University of Bahia (UFBA). This study was partially supported by a grant from the Conselho Nacional de Pesquisa (CNPq). Aceite: 29-junho-1995.

Dr. Ailton Melo - Departamento de Neuropsiquiatria, Faculdade de Medicina, UFBA - Av. Reitor Miguel Calmon s/n - 40110-100 Salvador BA - Brasil. 
gammopathy in serum, increased intrathecal IgG synthesis and oligoclonal bands in the cerebrospinal fluid (CSF) have suggested that immunological mechanisms are related to the development of the disease caused by HTLV-I ${ }^{5,11,12}$.

In this paper, we report that increased levels of bronchoalveolar lymphocytes are present in the majority of patients with HAM and this finding confirms the idea that the lung is one of the most important organs in the pathogenesis of HTLV-I infection.

\section{PATIENTS AND METHODS}

Study Populations. Thirty-five patients with non-traumatic and non-tumoral myelopathies were consecutively examined at the Neuroinfectology Unit of the Professor Edgard Santos Hospital, a university hospital in Salvador (Northeastern-Brazil) for lower income individuals. All participants in both the study and control groups underwent serological and CSF tests for HTLV-I.

The CSF from all participants was tested for cells, proteins, protein electrophoresis and infectious or parasitic diseases (syphilis, toxoplasmosis, cysticercosis and schistosomosis). All participants underwent either magnetic resonance or myelography of the spinal cord as well as a chest $\mathrm{X}$-ray, red blood cell count, arterial gasometric analysis, VDRL, EKG and a parasitological analysis of feces including the Baermann method.

Both the study and control groups fulfilled the clinical, serological and CSF diagnostic criteria for HAM that have been described previously.

Patients with a history of systemic diseases or pulmonary infections in the four months prior to analysis were excluded.

Pulmonary Function Tests. Each patient was submitted to forced vital capacity and forced expiratory volume in one second (FEV-1). The diffusing capacity was obtained using the single breath method and corrected for alveolar volume and hemoglobin levels.

Bronchoalveolar Lavage. Bronchoalveolar lavage was done using local anesthesia and mild sedation with midazolan by one certified specialist (LP). The fibroscope was always placed in the right middle lobe and $200 \mathrm{~mL}$ of sterile saline were instilled. The fluid was recovered by gentle aspiration into sterile jars and transported immediately to the laboratory. After the procedure, $0.5 \mathrm{~mL}$ of flumazenil was administered.

Transbronchial Lung Biopsy was carried out in one patient.

Statistical Analysis. A statistical analysis was done using the unpaired Student's $\mathbf{t}$ test. $\mathbf{P}$ values less than 0.05 were considered significant.

\section{RESULTS}

The study sample included 35 patients ( 22 from the study group and 13 from the control group) with non-traumatic and non-tumoral myelopathies admitted to Neuroinfectology Unit at the Federal University of Bahia. All patients were of African descent or mixed-race. The age of the study group ranged from 26 to 67 years; mean $48.2 \pm 9.9$. The age of the control group ranged from 26 to 60 years; mean $42.3 \pm 11.7$. The mean ages were not different when compared using the tstudent and Kruskal-Wallis tests. Physical examination did not show signs of lymphadenopathy, splenomegaly or hepatomegaly in either groups.

Pulmonary Findings. Sixteen out of the 22 participants in the study group denied having respiratory symptoms of any kind. Five $(22.7 \%)$ spoke of mild dyspnea during exercise and three $(13.6 \%)$ had intermittent dry coughs. No patients presented cardiovascular pathologies. None abused drugs. One patient with HAM had pulmonary fibrosis. All but one patient were non-smokers. The results of the pulmonary function tests were within the normal range for 9 (40.9\%) of patients in the study group. Six patients had a mild restrictive syndrome and three presented decreased diffusing capacity. No patients were hypoxemic. 


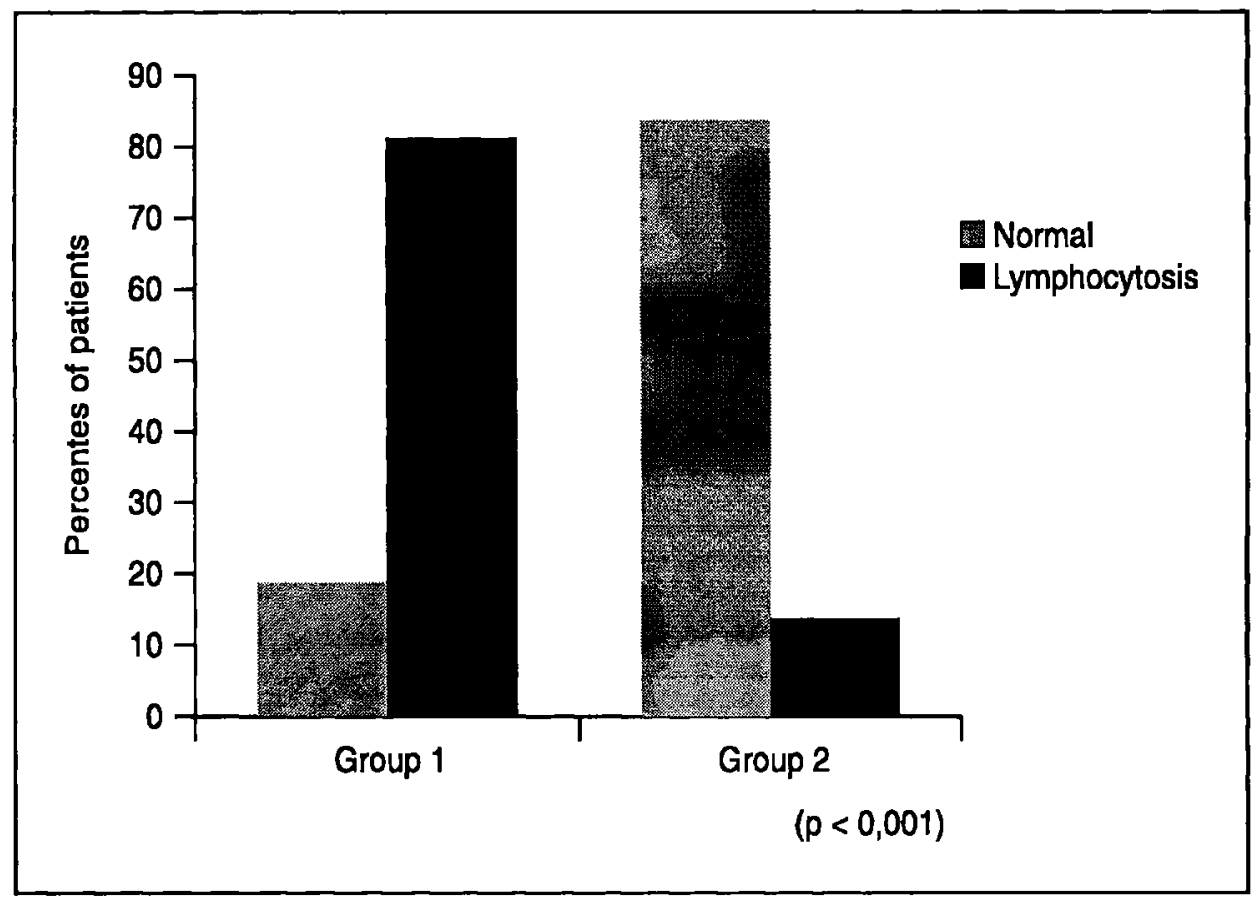

Fig. I. Comparisen of the BAL fluid in HAM (Group 1) and non HAM (Group 2) patients.

The results of the BAL fluid analyses in the control and study groups are shown in Figure 1. In the control group two patients (15.4\%) had lymphocytosis in the BAL fluid and in the study group 18 patients $(81.8 \%$ ) had a lymphocyte ratio of more than $20 \%$ of the alveolar cells.

The characteristics of the cells recovered from the bronchoalveolar lavage are summarized in Table 1. Specific stainings for Pneumocysts carinii were negative in both groups.

\section{DISCUSSION}

We detected pulmonary involvement in $88 \%$ of the 22 HAM patients compared to $15.4 \%$ of the control group. In the first paper that identified pulmonary involvement in patients with HAM in South America ${ }^{8}$, we showed that seven of eight patients had lymphocytosis in the bronchoalveolar fluid. Sugimoto et al. described T-lymphocytosis in the BAL fluid of $80 \%$ of the 15 patients with HAM in Japan $^{13,14}$ and Couderc et al. ${ }^{1}$ reported $76 \%$ of T-lymphocyte alveolitis of the 21 patients from Africa. These findings indicate that the lung represents an important organ in the pathogenesis of HAM.

As has been previously described, pulmonary involvement in the majority of HAM patients has been proved to be asymptomatic ${ }^{8,10,14}$. In our study 3 patients with HAM presented symptoms of dyspnea and coughing and 2 showed radiological images suggestive of interstitial lung disease. One of the patients presented mononuclear infiltration associated with interstitial fibrosis which leads us to believe that in some HAM patients the involvement of the lungs could evolve into chronic interstitial lung disease.

Recently, Sugimoto et al. ${ }^{14}$ reported that specific IgA antibodies were present in the BAL fluids of HAM patients with lymphocyte alveolitis, but were not detected in non-HAM carriers and HAM patients without alveolitis. These data and the findings of Jacobson et al. ${ }^{5}$, which found specific IgA antibodies in sera from eight patients with HAM, point to a link between an IgA immune complex and lung disorders in patients with HAM. 
Table 1 . Findings from the BAL fluid in HAM and control patients.

\begin{tabular}{|c|c|c|c|c|}
\hline \multirow[t]{2}{*}{ Patients } & \multicolumn{4}{|c|}{$\operatorname{BAL}(\%)$} \\
\hline & macrophages & lymphocytes & neutrophils & eosinophils \\
\hline \multicolumn{5}{|c|}{ HAM PATIENTS } \\
\hline 1 & 35.8 & 55.3 & 6.7 & 2.2 \\
\hline 2 & 23.3 & 72.0 & 4.2 & .05 \\
\hline 3 & 40.7 & 58.9 & 0.4 & 0.0 \\
\hline 4 & 49.5 & 48.8 & 2.4 & 0.0 \\
\hline 5 & 13.2 & 86.8 & 0.0 & 0.0 \\
\hline 6 & 83.5 & 15.6 & 0.0 & 0.8 \\
\hline 7 & 87.4 & 12.9 & 0.0 & 0.0 \\
\hline 8 & 47.7 & 54.4 & 1.9 & 0.0 \\
\hline 9 & 58.8 & 41.2 & 0.0 & 0.0 \\
\hline 10 & 36.3 & 57.0 & 6.7 & 0.0 \\
\hline 11 & 53.2 & 30.4 & 6.7 & 6.6 \\
\hline 12 & 16.5 & 75.8 & 7.7 & 0.0 \\
\hline 13 & 72.6 & 16.5 & 11.0 & 0.0 \\
\hline 14 & 89.9 & 6.6 & 3.9 & 0.0 \\
\hline 15 & 60.6 & 36.2 & 3.2 & 0.0 \\
\hline 16 & 24.0 & 74.3 & 1.7 & 0.0 \\
\hline 17 & 10.5 & 67.5 & 22.5 & 0.0 \\
\hline 18 & 50.8 & 47.6 & 1.6 & 0.0 \\
\hline 19 & 38.9 & 61.1 & 0.0 & 0.0 \\
\hline 20 & 69.4 & 24.5 & 5.9 & 0.0 \\
\hline 21 & 68.2 & 24.3 & 7.5 & 0.0 \\
\hline 22 & 30.0 & 57.2 & 12.7 & 0.0 \\
\hline Mean (SD) & $48.22(23.8)$ & $46.54(22.9)$ & $4.85(5.4)$ & $0.46(1.46)$ \\
\hline \multicolumn{5}{|c|}{ CONTROL PATIENTS } \\
\hline 1 & 22.8 & 67.8 & 9.2 & 0.0 \\
\hline 2 & 84.0 & 12.9 & 3.1 & 0.0 \\
\hline 3 & 81.4 & 16.0 & 2.6 & 0.0 \\
\hline 4 & 78.5 & 15.2 & 6.3 & 0.0 \\
\hline 5 & 87.2 & 12.7 & 0.0 & 0.0 \\
\hline 6 & 39.7 & 49.6 & 10.7 & 0.0 \\
\hline 7 & 78.5 & 15.2 & 6.3 & 0.0 \\
\hline 8 & 87.3 & 12.7 & 0.0 & 0.0 \\
\hline 9 & 77.8 & 14.1 & 8.1 & 0.0 \\
\hline 10 & 80.0 & 15.3 & 4.7 & 0.0 \\
\hline 11 & 97.0 & 03.0 & 0.0 & 0.0 \\
\hline 12 & 93.9 & 04.3 & 1.8 & 0.0 \\
\hline 13 & 87.1 & 10.5 & 4.4 & 0.0 \\
\hline Mean (SD) & $76.6(21.2)$ & $19.2(18.4)$ & $4.4(3.6)$ & 0.0 \\
\hline
\end{tabular}


In our opinion, as has been observed with several other infectious diseases, the lung is compromised by HTLV-I as soon as the virus reaches the circulatory system. However, the loading of proviral DNA seems to play an important role as well in the determination of T-lymphocyte alveolitis and myelopathy as has been pointed out by Mita et al. ${ }^{10}$. Thus, the detection of lymphocytosis in the BAL fluid represents the continued antigenic stimulation by the virus and a possible evolution to interstitial fibrosis which may be related to an interplay between host and virus.

The knowledge of the association between human leukocyte antigen haplotypes and the high level of immune responsiveness against HTLV-I, the similarities between the viruses detected in adult T-cell leukemia-lymphoma and in HAM patients and the pleomorphic clinical expression of HTLV-I infection ${ }^{12}$ suggest that aside from genetic determinants, there are environmental and/or infectious factors that play an important role in the pathogenesis and clinical presentation of this new syndrome.

Acknowledgements - We are indebted to Laboratorio de Imunologia of the Federal University of Bahia for the techinical immunological assistance.

\section{REFERENCES}

1. Couderc LJ, Caubarrere I, Venet A, Magdeleine J, Jouanelle A, Danon F, Buisson G, Vernant JC. Bronchoalveolar lymphocytosis in patients with tropical spastic paraparesis associated with human T-cell lymphotropic virus type-I (HTLV-I). Ann Intern Med 1988, 109:625-628.

2. Gessain A, Barin F, Vernant JC, Gout O, Maurs L, Calender A, De Thé G. Antibodies to human Tlymphotropic virus type I in patients with tropical spastic paraparesis. Lancet 1985, 2:407-410.

3. Gessain A, Gout $O$. Chronic myelopathy associated with human T-lymphotropic virus type I (HTLV-I). Ann Intern Med 1992, 117:933-946.

4. Higuchi I, Montemayor ES, Izumo S, Inose M, Osame M. Immunohistochemical characteristics of polymiositis in patients with HTLV-I associated myelopathy and HTLV-I carriers. Muscle and Nerve 1993, 16:472-476.

5. Jacobson S, Gupta A, Mattson D, Mingioli E, McFarlin DE. Immunological studies in tropical spastic paraparesis. Ann Neurol 1990, 27:149-156.

6. Kano M, Mitsuhata Y, Kishida S, Yano Y, Muro T, Shy-Drager syndrome and human T-lymphotropic virus infection. Ann Neurol 1989, 25:420-421.

7. Lessa I, Moraes D, Meireles A, Melo A. HTLV-I and myelopathy in Salvador (Northeastern Brazil): a casecontrol study. Arq Neuropsiquiatr 1993, 51:447-451.

8. Mattos K, Queiroz C, Peçanha-Martins AC, Publio L, Melo A. Lymphocyte alveolitis in HAM/TSP patients. Arq Neuropsiquiatr 1993, 51:134-136.

9. Melo A, Gomes I, Mattos K. Mielopatias por HTLV-I na cidade de Salvador, Bahia. Arq Neuropsiquiatr 1994, 52:320-325.

10. Mita S, Sugimoto M, Nakamura M, Murakami T, Tokunaga M, Uyama E, Araki S. Increased human T-lymphotropic virus type-I (HTLV-I) proviral DNA in peripheral blood mononuclear cells and bronchoalveolar lavage cells from Japanese patients with HTLV-I associated myelopathy. Am J Trop Med Hyg 1993, 48:170-177.

11. Moreira ED Jr, Ribeiro TT, Swanson P, Sampaio C, Melo A, Brites C, Badaró R, Toedter G, Lee H, Harrington W Jr. Seroepidemiology of human T-cell lymphotropic virus type I/II in Northeastern Brazil. J AIDS 1993, 6: 959-963.

12. Osame M, Igata A, Matsumoto M, Kohka M, Usuku K, Izumo S. HTLV-I associated myelopathy (HAM): treatment trial, retrospective survey and clinical and laboratory findings. Hematol Rev 1990, 3:271-284.

13. Osame M, McArthur JC. Neurologic manifestations of infection with human T-cell lymphotropic virus type I. In Asbury AK, McKhann GM, McDonald WI.(eds). Disease of the nervous system:clinical neurobiology Philadelphia Saunders, 1992 p 1331-1339.

14. Sugimoto M, Nakashima $H$, Kawano O, Ando M, Araki S. Bronchoalveolar T-lymphocytosis in HTLVI associated myelopathy. Chest 1989, 95:708.

15. Sugimoto M, Imamura F, Matsumoto M, Sonoda E, Cho I, Ando M. Pulmonary involvement in patients with human T-lymphotropic virus type I-associated myelopathy: the presence of specific IgA antibody in bronchoalveolar lavage fluid. Am J Trop Med Hyg 1993, 48:803-811. 